\title{
Comparison between the anesthetic induction times in the first and second surgery in rabbits ${ }^{1}$
}

\author{
Comparação entre os tempos de indução anestésica no primeiro \\ e segundo atos operatórios em coelhos
}

\begin{abstract}
Victor Araujo Felzemburgh", Queise da Costa Cettolin"I, Klenio Menezes Machado", José Humberto Oliveira Campos ${ }^{\text {II }}$
IMD, Volunteer Faculty, Division of Surgical Technique and Experimental Surgery I, EBMSP, Salvador-BA, Brazil. Main author. Responsible for conception, design, intellectual and scientific content of the study.

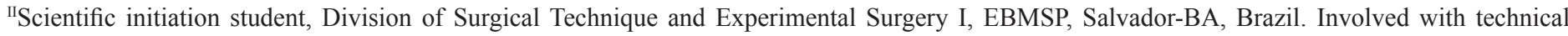
procedures and acquisition of data.

IIIPhD, Full Professor, Division of Surgical Technique and Experimental Surgery I, EBMSP, Salvador-BA, Brazil. Conception, design of the study and critical revision.
\end{abstract}

\begin{abstract}
PURPOSE: To compare the anesthetic induction time (IT) in the first and second surgery in rabbits.

METHODS: Eighteen rabbits, weighing between 1.825 and $2.980 \mathrm{~kg}$. The anesthetic protocol consisted of premedication of ketamine and xylazine intramuscularly. The rabbits were anesthetized and the induction time was evaluated by compressing the animal's ear every 30 seconds. The IT was measure and than a saphenous vein surgery was made on the rabbit. Seven days after the first procedure, the same anesthetic protocol was performed and measuring the second IT.

RESULTS: It was observed an increase of 50 seconds on the average value of second IT in relation to the average value of first. The IT variation between the first and second anesthetic procedure was between 0 and eight minutes for each animal. In $94.4 \%$ of the animals, there was variation greater than 30 seconds between the IT.
\end{abstract}

CONCLUSION: There was difference between the first and second induction time in almost animals. There was an increase on the average value of second IT in relation to the average value of first.

Key words: Anesthesia. Injections, Intramuscular. Ketamine. Xylazine. Rabbits.

\section{RESUMO}

OBJETIVO: Comparar os tempos de indução anestésica (TIA) no primeiro e segundo atos operatórios em coelhos.

MÉTODOS: Foram utilizados 18 coelhos de peso entre 1,825 e 2,980kg. O protocolo anestésico consistiu de pré-medicação de ketamina e xilazina por via intramuscular. Os coelhos foram anestesiados e o tempo de indução anestésica foi avaliado por meio da compressão da orelha do animal a cada 30 segundos. O TIA foi medido e em seguida foi realizada cirurgia na veia safena do coelho. Depois de sete dias do primeiro procedimento, o mesmo protocolo anestésico foi realizado e o segundo TIA foi medido.

RESULTADOS: Foi observado um aumento de 50 segundos na média dos tempos de indução anestésica da segunda medida em comparação com a média do primeiro. A variação do TIA entre o primeiro e segundo protocolo anestésico foi de 0 a oito minutos. Em $94,4 \%$ dos animais a variação entre os tempos foi maior que 30 segundos.

CONCLUSÃO: Houve diferença entre o primeiro e o segundo tempo de indução anestésica em todos os animais. Houve aumento na media dos valores do segundo TIA em relação ao primeiro TIA.

Descritores: Anestesia. Injeções Intramusculares. Ketamina. Xilazina. Coelhos. 


\section{Introduction}

The use of animals in biomedical research has been recommended for improvement and validation of existing procedures, developing new methodologies and understanding of the diversity of physiological and pathological processes. This fact stems from the lack of in vitro models able to fully simulate the complexity of the human body ${ }^{1}$.

The consensus is that the animals are essential for teaching and experimental research. Animals are fundamental to the progress of medicine in the prevention and diagnosis, and especially, in the treatment ${ }^{2}$.

Rabbits are widely used for experimental surgery. These animals are small, low cost, with an easy venous access and have a considerable number of anatomical and physiological characteristics that are useful for research ${ }^{3,4}$.

It's possible to say that a dose sufficient to kill a rabbit, can be considered weak to affect the other ${ }^{3}$. Thus, the study of factors that influence the response to anesthetic procedures is essential to improve the arsenal of knowledge about experimental surgery in rabbits and reduce the morbidity of the procedures, as well as provide the appropriate choice of anesthetic protocol for each procedure ${ }^{3}$.

\section{Methods}

The study protocol was analyzed and approved by the Ethic Commission on Animal Research of Bahiana School of Medicine and Public Health (EBMSP). The use of laboratory animals followed the ethical code for animal experimentation of the Council for International Organization of Medical Sciences.

Eighteen rabbits were used, (Oryctologus cuniculus), male, New Zealand race, aged between two to three years, from 1.825 to $2.980 \mathrm{~kg}$, from EBMSP. The animals were introduced in adaptation five days before surgery, with humidity averaging $50 \%$ and a temperature of $22^{\circ} \mathrm{C}$. Pellet food were used twice daily associated with water ad libitum.

\section{Anesthetic protocol}

For the anesthetic technique, food and water was removed for eight hours before anesthesia. The anesthetic protocol adopted consisted of premedication with ketamine $35 \mathrm{mg} / \mathrm{kg}$ and xylazine $16 \mathrm{mg} / \mathrm{kg}$, intramuscularly applied to the left lateral thigh ${ }^{4-6}$.

\section{Evaluation of induction time}

One member of the team of the research project anesthetized all animals according to the protocol above and evaluated the time of anesthetic induction with a compression on the animal's ear every 30 seconds, using a serrated forceps (often called mouse's teeth). This evaluation of the induction time (IT) was performed on all animals on two occasions: the first, immediately before the surgical procedure in the thigh of the animal, the second seven days after surgery.

The animals, after undergoing the first anesthesia, were placed in dorsal decubitus on the operating table suitable for rabbits. Trichotomy in the ventral portion of the thighs and asepsis was made. Two incisions were made $3 \mathrm{~cm}$ : one in the right thigh and the other in the left thigh of the animal, with dilatation of the subcutaneous tissue and performed ligatures on saphenous vein with cotton thread 4.0 (Figure 1). After the procedure the skin was closed with simple stitches with Nylon 5.0.

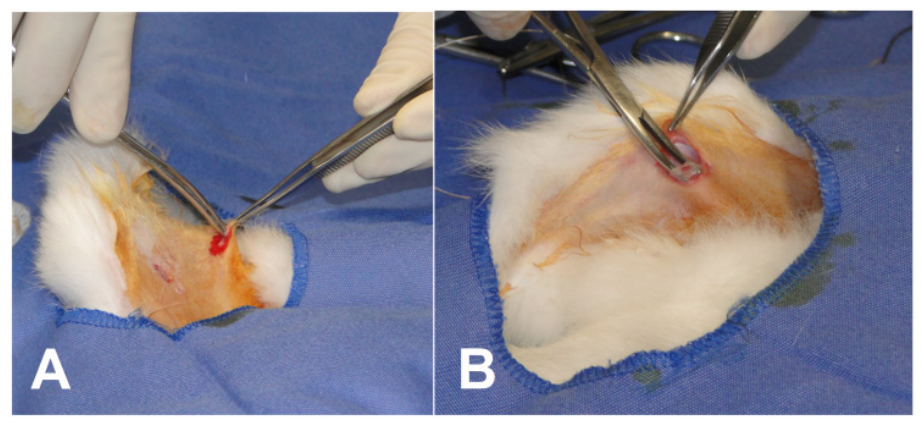

FIGURE 1 - Saphenous vein ligature. A. Dilatation of subcutaneous tissue. B. Exposure of the vessel.

The postoperative pain was investigated to determine if the animal needed more analgesia administration. Because it is a mild procedure, minimally invasive analgesia was performed with acetaminophenol at a dose of $1 \mathrm{ml}$ per $100 \mathrm{ml}$ of water in the first postoperative day ${ }^{7}$.

Indicators such as motor activity, changes in appearance, temperament, vocalization, consumption of food or water and physiological changes were assessed. The presence of edema and erythema at the surgical site was also evaluated because they represent important indicators of a pain.

\section{Results}

The induction times (ITs) was between one and 12 minutes throughout the experiment. The IT variation between the first and second anesthetic procedure was between 0 and eight minutes for each animal.

In $94.4 \%$ of the animals, there was variation greater 
than 30 seconds between the ITs, between the first and second anesthetic protocol. Only 5.6\% showed no change in IT.

In $44 \%$ of the animals present difference between the both ITs up to two minutes. And $72 \%$ of the animals present difference between both ITs within three minutes. Eleven rabbits presents increased variation of the IT (Figure 2).

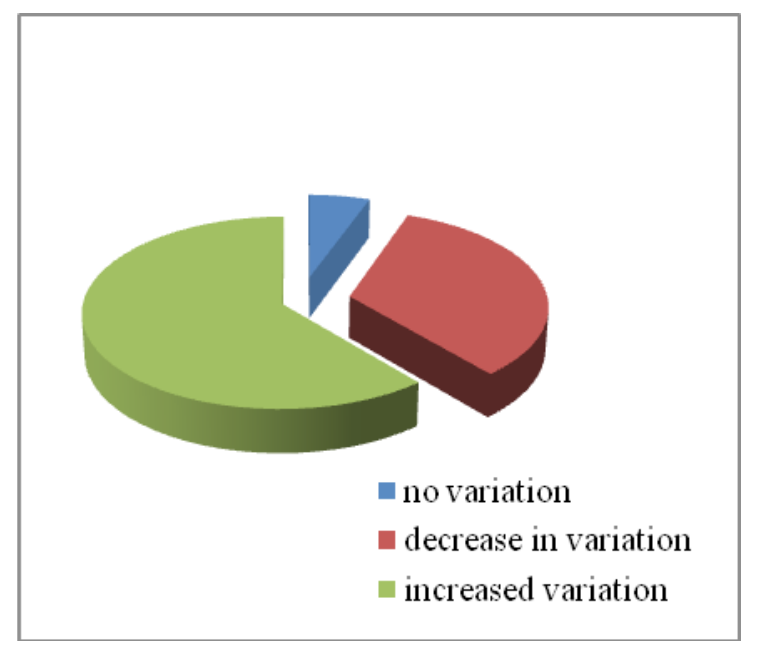

FIGURE 2 - Variation of induction time. One animal didn't change the IT (blue). Six rabbits presents decrease in variation (red). Eleven animals presents increased variation (green).

The average animal weight was $2323 \mathrm{~g}$. There was no statistically significant relationship between the IT variation and the weight of the animals before the procedure, $\mathrm{p}=0.294$, T student Test (Figure 3).

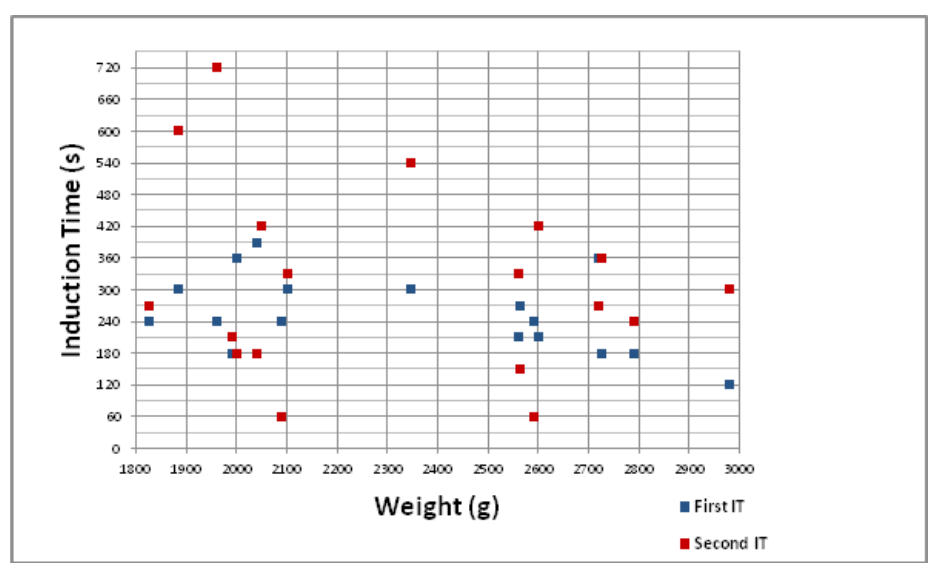

FIGURE 3 - Relationship between the first induction time (IT) measure and the second of each animal with the respective rabbit weight. First IT (blue), second IT (red).

It was observed an increase of 50s on the average value of second IT in relation to the average value of first IT. The IT before the procedure ranged from 120 to 420 s, and their average $263.3 \mathrm{~s}$. The IT after the procedure ranged from 60 to $720 \mathrm{~s}$, and their average was $313.3 \mathrm{~s}$ (Table 1).
TABLE 1 - Induction time of the first and the second anesthetic procedure and the respective weights.

\begin{tabular}{ccccc}
\hline $\begin{array}{c}\text { Rabbit } \\
\text { Number }\end{array}$ & $\begin{array}{c}\text { IT } \mathbf{1} \\
\text { (s) }\end{array}$ & $\begin{array}{c}\text { IT } 2 \\
\text { (s) }\end{array}$ & $\begin{array}{c}\text { VIT } \\
\text { (s) }\end{array}$ & $\begin{array}{c}\text { Weight } \\
\text { (g) }\end{array}$ \\
\hline $\mathbf{1}$ & 210 & 420 & 210 & 2600 \\
$\mathbf{2}$ & 180 & 240 & 60 & 2790 \\
$\mathbf{3}$ & 240 & 270 & 30 & 1825 \\
$\mathbf{4}$ & 180 & 360 & 180 & 2725 \\
$\mathbf{5}$ & 240 & 60 & 180 & 2590 \\
$\mathbf{6}$ & 390 & 180 & 180 & 2040 \\
$\mathbf{7}$ & 210 & 330 & 120 & 2560 \\
$\mathbf{8}$ & 360 & 270 & 90 & 2720 \\
$\mathbf{9}$ & 270 & 150 & 120 & 2565 \\
$\mathbf{1 0}$ & 300 & 540 & 240 & 2345 \\
$\mathbf{1 1}$ & 420 & 420 & 0 & 2050 \\
$\mathbf{1 2}$ & 300 & 330 & 30 & 2100 \\
$\mathbf{1 3}$ & 360 & 180 & 180 & 2000 \\
$\mathbf{1 4}$ & 300 & 600 & 300 & 1885 \\
$\mathbf{1 5}$ & 180 & 210 & 30 & 1990 \\
$\mathbf{1 6}$ & 240 & 720 & 480 & 1960 \\
$\mathbf{1 7}$ & 240 & 60 & 180 & 2090 \\
$\mathbf{1 8}$ & 120 & 300 & 180 & 2980 \\
\hline
\end{tabular}

IT1 $=$ First induction time IT2 $=$ Second induction time VIT $=$ Variation of induction time

\section{Discussion}

For this study, the rabbit was the animal chosen to perform the experimental model due to it being widely used in experimental surgery with anatomy similar to humans. Moreover, the need to create an experimental model of education involving venous dissection favored the choice of the rabbit. The saphenous vein of this animal fit important parameters for the realization of the surgical technique, such as the size suitable for handling and execute the vessel ligation ${ }^{8}$.

The IT study is important to add knowledge to the arsenal of information for all kind of experimental procedures with rabbits. This research project can provide data for other similar studies, showing a variation up to three minutes between the procedures, to about $72 \%$ of animals. However, the variation between the first IT and second was between 0 and eight minutes. This kind of information can interfere with the logistics of surgical procedures.

Oryctolagus cuniculus are often used in a wide variety of experiments, including different surgical specialties. However, information on handling and surgical procedures are sparse and difficult to find ${ }^{1}$.

In the research project, it chose the anesthetic protocol mentioned above due to its wide use in the literature ${ }^{4-6}$ addition to 
deal with a safe and easy to perform. This protocol promotes good muscle relaxation and analgesia for the animal without severe cardio-respiratory depression?

It is reported that the depth of anesthesia is assessed by the response to ear pinch, palpebral and corneal $\operatorname{reflex}^{4,7}$. The clamping of the animal's ear was the procedure of choice because it is a procedure commonly reproducible and simple to perform.

The use of intubation anesthesia technique permits better control of the airways, including the possibility of measuring the concentration of $\mathrm{CO}_{2}$ gas inhaled and exhaled by capnography. For this type of anesthesia relaxation of the rabbit is important and can be administered ketamine and xylazine or face mask with isoflurane and $\mathrm{O}_{2}$ for induction ${ }^{9}$. In our anesthetic protocol performed by a procedure to treat mild severity, minimally invasive and safe, there was no need more deep anesthesia, which could reflect a greater morbidity to the animal.

Often, rabbits are considered difficult to numb due in part to problems with intubation, the shape of the oral cavity of these animals prevents the visualization of the larynx, and also because these animals are highly susceptible to respiratory arrest $\mathrm{t}^{3,10}$. Securing the airway is essential to maintain adequate ventilation during the anesthesia ${ }^{10}$. The anatomy difficult the intubation of the traquea, the tongue is very long, possessing in its base a prominent, the teeth are long hindering the visualization of the glottis ${ }^{11}$.

Anesthetic agents are selected based on the health of the animal, the duration and invasiveness of the procedure. Intramuscular agents can be used to produce immobilization and if adequate analgesia is present can produce surgical anesthesia ${ }^{1}$.

The substance is injected into the skeletal muscle in the form of oily solutions or suspensions. The muscles of large surface, such as the posterior portion of the posterior muscles of thighs are the most used areas. The needles used should be with the similar size to those employed in subcutaneous injections and depth in the tissue should be approximately $5 \mathrm{~mm}$. Bony structures, nerves and blood vessels must be avoided. In this study, was decided to use the thigh muscle of the animal because of the ease of handling. During the injection of the substance, there were no difficulties. The doses used in animals according to the protocol mentioned, ranged between 1.3 and $2.1 \mathrm{ml}$ of ketamine and 1.5 to $2.4 \mathrm{ml}$ xylazine.

Ketamine alone produces immobility in animals due to a significant increase in skeletal muscle tone. When administered in combination with a tranquilizer (acepromazine, diazepam or midazolam) or xylazine or medetomidine, muscle relaxation is improved and the duration of anesthesia is prolonged ${ }^{1,4}$. These combinations can produce significant respiratory depression and should always be associated with oxygen supplementation ${ }^{1}$.

Intubation of rabbits has been described as technically difficult and time consuming ${ }^{9,10}$. However is described by the author in a study of an experimental model for tracheal cannulation, 33 rabbits aged between five and seven months, which was carried out without the technical view of the glottis successfully ${ }^{3}$. Another study also presented a rate of $100 \%$ success and there were no complications such as trauma, laryngeal spasm, postoperative hemorrhages or breathing faliure ${ }^{11}$.

In addition to difficulties in intubation, other factors affect the response of rabbit to anesthetics. Rabbits have high concentrations of circulating catecholamines. A sudden change may lead to an increased circulation of catecholamines leading to a fatal cardiac arrhythmia ${ }^{7}$. In our research project there was no death, underscoring the importance of performing the procedure in a controlled environment for not subjecting the animal to stress and hormonal changes. The anesthetic protocol was safe.

The realization of a previous surgical procedure showed interfere with IT, and $94.4 \%$ of the animals showed differences in the second IT in relation to the first. It was also observed that $72 \%$ of the animals in the TIA did not vary more than 3 minutes. However, it was not possible to exclude all factors known that can influence the IT. The specific factors that influence this response are: sex, age, strain, body weight, body fat percentage, nutritional status, gastrointestinal contents, time of day and genetic variants and respiratory and metabolic rate ${ }^{3}$.

The education and experimental research in the medical field is structured on the availability of animals for experimentation and it is important and necessary for the personal and scientific development of the future physician ${ }^{2}$. However it should also follow the principles of human animal experimentation proposed by Russell and Burch namely, replacement, reduction, and refinement ${ }^{12}$.

The understanding of the use of experimental animals in scientific research and teaching is sometimes an intricate matter ${ }^{2}$. The use of animal experimentation is a much discussed topic. Therefore, it is important to broaden the knowledge of animal models, permitting the increase of safer procedures, avoiding higher morbidity or suffering to the animal.

\section{Conclusion}

There was difference between the first and second induction time in almost animals. There was an increase on the average value of second IT in relation to the average value of first. 


\section{References}

1. Calasans-Maia MD, Monteiro ML, Áscoli FO, Granjeiro JM. The rabbit as an animal model for experimental surgery. Acta Cir Bras. 2009;24(4):325-8.

2. D'Acampora AJ, Rossi LF, Ely JB, Vasconcellos ZA. Is animal experimentation fundamental? Acta Cir Bras. 2009;24(5):423-5.

3. Balbinotto RP, Trindade MRM, Meyer FM, Rosa Junior A, Muller ALL, Nunes AG, Silva R. Anesthetic protocol for videolaparoscopic surgery in rabbits. Acta Cir Bras. 2010;25(1):121-5.

4. Fonseca NM, Goldenberg S, Gomes PO, Lima CAP. Anestesia em coelhos. Acta Cir Bras. 1996;11(2):82-104.

5. Imamura R, Sennes LU, Chung D, Bohadana S, Tsuji DH. Injeção de gordura na prega vocal: efeitos do local de injeção sobre a configuração glótica e a distribuição espacial da gordura injetada. Rev Bras Otorrinolaringol. 2003;69(4);445-50.

6. Nakao M, Inoue CM, Aydos RD, Silva IS, Goldenberg S. Efeitos da ressecção parcial da cartilagem do septo nasal no desenvolvimento dos ossos da face de coelhos em crescimento. Acta Cir Bras. 1999;14(1):3-6

7. Damy SB, Camargo RS, Chammas R, Figueiredo LFP. Aspectos fundamentais da experimentação animal - aplicações em cirurgia experimental. Rev Assoc Med Bras. 2010;56(1):103-11.

8. Kapinski M, Lahiri A, Lim AY. Different angiogenic behaviour of ligated saphenous and epigastric vascular bundles in avascular environment: an in-vivo experimental study. Hand Surg. 2010;15(1):17-25.

9. DeValle JMS. Sucessful Management of rabbit anesthesia through the use of nasotraqueal intubation. J Am Assoc Lab Anim Sci. 2009;48(2):166-70.

10. Imai A, Eisele PH, Steffeney EP. A new airway device for small laboratory animals. Lab Anim. 2005;39(1):111-5.

11. Falcão SC, Pereira Junior JR, Coelho ARB. Technique of blind tracheal intubation in rabbits (Oryctolagus cuniculi) supported by previous maneuver of esophageal cannulization. Acta Cir Bras. 2011;26(5):352-6

12. Balls M, Straughan DW. The three Rs of Russell \& Burch and the testing of biological products. Dev Biol Stand. 1996;86:11-8.

\section{Correspondence:}

Victor Araujo Felzemburgh

Avenida Juracy Magalhães Junior, 670

41960060 Salvador - BA Brasil

Tel.: (55 71)3346-4570

victor@ccp.med.br

Received: February 15, 2012

Review: April 12, 2012

Accepted: May 14, 2012

Conflict of interest: none

Financial source: none

${ }^{1}$ Research performed at the Nucleus of Experimental Surgery, Bahiana School of Medicine and Public Health (EBMSP), Salvador-BA, Brazil. 